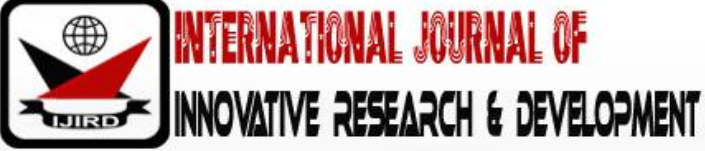

ISSN 2278 - 0211 (Online)

\section{Examining the Influence of Job Training-Fit on Employee Creativity and Performance: A Case Study of the Ghana Police Service}

David Yevugah
Ph.D. Candidate, Department of HR and Organizational Behavior,
Noble International Business School, Ghana
Dr. Livingstone Caesar
Associate Professor, Department of Management and Organisational Behaviour,
Noble International Business School, Ghana

\begin{abstract}
:
The importance of having a job that is different from the one for which one is trained for has become very important in recent times given the huge costs organizations incur with regards to the training of their staff. Generally, there is a consensus within the literature that, employee become more creative when they are given the right training. The purpose of this paper is to investigate the influence of job training-fit on employee creativity performance in the Ghana Police Service. A qualitative approach was used for this study. A Case study was the design chosen for this research. The participants were selected using purposive sampling. A homogenous sample was used to select Police Officers between the ranks of Constables to Assistant Commissioner of Police from various departments in order to concentrate on issues related to the influence of job training-fit on employee creativity and performance. Unstructured interviews were conducted within The Police Service on the basis of relevance to the topic of this study. A total of 11 participants were interviewed in their various workplaces. The findings of this study revealed specific training programs targeted at the duty personnel perform is what is needed to improve personnel creativity and performance. This study recommends collaborations between stakeholders and other professionals with specialized, well planned and systematic training to provide an innovative approach to addressing issues relating to job training-fit.
\end{abstract}

Keywords: Job training-fit, Ghana police service, performance, training, personnel

\section{Introduction}

The era of globalization and high technology has continuously shifted the political and economic landscape (Wood \& Budhwar, 2016), forcing companies and business alliances to rethink their strategies. Businesses that span the world are becoming a norm and they continuously formulate strategies to expand their markets and extend their reach. These strategies include the need to accommodate an increasingly demanding, agile, mobile workforce and talented staff with the right skills for the job (Schuler, Jackson, \& Tarique, 2011). Hence, the major challenges that organizations face is the ability to systematically manage their workforces to sustain competitiveness. According to Schuler, et al., (2011), the fluctuating aspects of globalization, the necessity for new capabilities, skills and enthusiasm, the emergence of new demographics, and the scarcity of talented and competent work force drive these global challenges. It is therefore necessary for organizations to elaborate more Human Resource Management (HRM) approaches to sustainable performance. Delbridge and Keenoy (2010) contended that organizations should move beyond the examination of a decontextualized human resource management towards a more holistic appreciation of the world of work and focusing on developing the capabilities, skills and knowledge by providing employees with training that fit the job they do. One of the important subsystems within the comprehensive human resource management system is training and development (Treven, 2001). Through training and development, the employees who have entered organizational domains with diverse educational backgrounds and personality orientations are brought in line with the requirements of the organization so that organizational tasks get accomplished which in turn assists organizations to move in the desired direction (Bhat, 2013; Diamantidis \& Chatzoglou, 2012).

Training and development are essential to the efficient use of an organization's human resources and an integral part of its planning process. In a dynamic society, training-fit is not an activity that is only desirable, but an activity that an organization must commit its resources, if it is, to maintain a viable and knowledgeable workforce (Obisi, 2011). Organizations are more likely to achieve this synergy when they review their recruitment and selection processes, design an appropriate training system, empower the workforce, promote and develop from within, and use teams to achieve goals. The Ghana police service is labor-intensive that depend on the knowledge, abilities and other characteristics of its 
employees be successful. There is therefore the need to develop progressive HRM practices. Modern policing is primarily not about changes in laws or regulations, but about changing attitudes, behavior, organization and the management and development of its human resources. The Ghana police service is seen as the face of the government by the public and, in this role, it provides internal security for the citizenry. Past studies and reports (Abudu, Nuhu \& Nkuahet, 2013; Bellamy \& Williams 2013; IEA Policy

Analysis, 2007) has stressed that the skills and capabilities of personnel of the Ghana Police Service make it difficult for the service to achieve its core functions of protecting life and property, preventing and detecting crime, apprehension and prosecution of offenders and maintaining public order. This has made the Ghana Police Service to lack the required capacity of a modern police organization and therefore been perceived as an ineffective organization (Archer, 1997). The Ghana police service has the highest number of security personnel as compared to the other sister security services. Nevertheless, statistics show that due to lack of the right skills and the right work environment, performance of personnel in the service tends to be low (CHRI, 2007). This has affected the personnel capabilities in the delivery of the expected standard of performance (Aris, 2007). Research by organizational behavior theorist have revealed the manifestation of a good fit between training personnel and the duties they perform as vital (Kristof-Brown, Zimmerman \& Johnson, 2005) due to the fact that employees feel a sense of consideration and pay back the organization by exhibiting engaged behavior. This engaged behavior gives them the courage to achieve more than their responsibilities and results in advancement in the organization (Saks, 2006). The continuing critique of the Ghana Police Service for lack of capacity and required skills, police officers' involvement in crime, the widespread misuse of human rights, and governmental disturbance in its management (CHRI, 2007), call for investigations into whether the issue is the incompatibility between the training organized by the Ghana police service and the duties performed by personnel of the service. Although the efficiency of the Ghanaian police is ranked highly on the political agenda, comparative data and empirical information on administration of training and their performance are surprisingly rare. Therefore, the influence of training on the creativity of personnel and job performance in the Ghana Police Service remains a challenge. Moreover, most of the existing scholarly work on training and job performance concentrated on industrial settings and neglected the security services like the Ghana Police Service.

Empirical research on training in the Ghana Police Services literature is also rare. It is, therefore, the need to fill this gap to extend the frontiers of knowledge on the aforementioned theme that this study focuses on the influence and relevance of training-fit on personnel performance in the Ghana police service. The Ghana Police Service may see it, training budgets, reduce in the coming years as government puts stringent fiscal policies in place. This means training assessment in the service is needed to ensure prudent use of the training resources. This study provides the Ghana Police Service with a better insight into the mechanics of training assessments and the impact of job training fit on performance. It also helps with the policy directions of the Ghana Police Service regarding planning, developing and execution of efficient and effective training needs that will lead to improved efficiency in the performance in the Ghana police service. This study helps to avoid the introduction of training schemes that may yield no benefit to the Ghana Police Service but rather become a drain on the existing scarce resources.

This paper therefore aims at examining the influence of job training-fit on performance. Also, this paper attempts to explore if the Ghana Police Service conduct training needs assessment to ensure training organized in the service fit into the duties of police personnel. How often are the training syllabuses reviewed? Does the training given to police personnel by the Ghana Police Service fit the duties they perform?

\section{Review of Related Literature}

\subsection{Training-Fit and Employee Performance}

As one of the major activities of human resource management, training has for long been recognized to improve and develop employee performance (Sultana, Irum, Ahmed \& Mehmood, 2012). Training is defined by Mullins (2007) as the right supply of skilled and competent staffs who are working on a way to achieve the goals of the organizations. It enables employee to get information and get to know how they will be able to perform their job. This will help to increase the productivity levels of workers and also improves the services of the worker and brings optimistic change in the organization (Ameeq \& Hanif, 2013). However, organizations are to ensure the existence of congruence between the type of training (fit) and the job as this may affect performance of the employee. Further to this, Barrett and O'Connell (1998) contended that that when training is specific, employees better understand their job roles and responsibilities which translate into a bigger impact on wages and productivity. Kristof-Brown (2000) defines fit as the congruence between need, values or abilities of an individual and the culture or the environment of an organization or the job. Yevugah and Caesar (2018) defined job training-fit as the capacity of an employee training program to enhance the expertise, behavior and motivates employees to satisfy their job demands. Job training-fit is efficient tools that can help organizations improve on their performance (Rowden, 2002). It helps employees to feel more adjusted with their job allowing for more innovativeness on the job (Mason, Ark \& Wagner, 1996).

When training is well planned and undertaken regularly based on the demands of employees, its effect is strong and significant this leads to positive effect on organizational performance (Cosh, Hughes, Bullock \& Potton, 2003). However, other researchers contended that training does not only improve the overall performance of the employees to perform effectively on their current job, but also enhances their knowledge, skills and abilities (Guest, 1997: Wright \& Geroy, 2001). There is therefore a clear indication that when training is organized well to fit employees' jobs, there will be a positive upsurge in the knowledge, skills and attitude of employees which are necessary for both their current and future jobs. By this, the employees contribute to superior performance of the organization. Apart from these facts, some 
researchers contend that training leads to increase in employee commitment level, well-being and sense of belonging towards the organization, this they directly strengthening the organization's competitiveness in the business environment (Acton \& Golden, 2003; Karia \& Ahmad, 2000).

Findings from Bartlett (2001 p. 349) establishes a better link between organizational commitment and workplace training. He recommended that organizations "adopt new research methods to demonstrate to organizational decision makers that training that fit the jobs that employees do contributes to desired workplace attitudes which may in turn influence employee performance". It is therefore important that in determining the most efficient training method, there is the need for organizations to consider the characteristics like skill, attitude and job-related issues (Wexley \& Latham, 2002). This will ensure that the training provides a solution to cover performance issues, such as filling the gap between the standard and the actual performance (Swart, Mann, Brown \& Price, 2005). The training processes in itself must be systematic to allow for employees' performance enhancement (Obisi, 2011) to reinforce the employee competencies and enables them to execute their assigned tasks effectively and efficiently (Sahinidis \& Bouris, 2008).

Even though training can induce positive, there are some negative impressions that organizations might not see good and attitudes that trainees might carry with them into the workplace (Tannenbaum \& Colleagues, 1991). According to Becker (1993) the needed skill development which employees get as a result of training might not just be applicable at the current place of work, but also at other organizations throughout the labor market. This therefore discourages most employers to invest in training because it affords employee skill development that can used to work with another organization. Becker (1993) further argued that the organization will have pay wages that coincides with newly learned skills and performance level within a competitive labor market. If organizations fail to increase pay wages, they are at risk of losing them to their competitors who may be willing to pay more. According to Glance, Hogg and Huberman (1997), organizations often prefer to steal newly trained employees because of an upsurge in skills, knowledge and capabilities couple with their high-level performance. This they said can lead to organizations losing the entire investment made to employee train.

Given these arrays of impact that training has on employees, there is a dire need for organizations To ensure the introduction and the entrenchment of training packages that aligns with not only their corporate goals, but with the individual career ambitions of their employees. Also, the impact of training on attitudes suggests that it possesses the ability to influence performance and other innate skills among employees. This discussion, so far, asserts that a significant positive relationship exists between training fit and employee performance.

\subsection{Job Training- Fit and Intrinsic Motivation}

Researchers also have found that preschool motivation amplifies the positive relationship between intrinsic motivation and creativity (Grant \& Berry, 2011; Li \& Bai, 2015). Personal and contextual antecedents may affect preschool motivation and subsequently, creativity (Bolino \& Grant, 2016; Grant \& Berg, 2011). A crucial factor in employee creativity and performance is intrinsic motivation orientation (Amabile, 1996). Intrinsic motivation as defined by Amabile (1996) is the motivation that comes from the interest an individual has and participation in the task itself. It centers on competence, relatedness and the need for autonomy (Gagné \& Deci, 2005), or the characteristics of the design of the work leading to creative psychological states.

In the job training-faith context, current reviews have shown that more studies need to be done on how perceptions of training relevance to a job and the willingness to learn affect motivation (Chen \& Klimoski, 2007; Kraiger \& Ford, 2007). An understanding of how intrinsic motivation impacts the desire of workers to be trained could help in the formulation of pragmatic policies that effectively positions an employer as a learning organization and as an employer-of-choice. Roca and Gagné (2008) stated that when job training-fit is highly perceived it could contribute to need fulfillment. Additionally, the necessity of creativity and capability might be achieved through the encouragement of employees to pursue a challenges ideal for the development of their respective capacities. Therefore, due to the essential aspects of the work employees perform, they are likely to enjoy their work when motivated intrinsically. Amabile, (1996) defined creativityrelevant skills and processes as "a person's abilities, both innate and developed, to generate creative ideas and to creatively identify, explore, and solve problems".

\subsection{Job Training-Fit and Task-Relevant Skills and Knowledge}

There is the likelihood to have employees with a significant repertoire of knowledge, skills, and task-relevant skill to perform their jobs when job training-fit with an organization is high (Amabile, 1983). Hastie \& Dawes (2001) argued that individuals have the tendency to observe and comprehend events based on what they know and believe. Hence, with relevant, right values and orientations about the job employees, there is the likelihood organizational event and workrelated issues will be better understood by the employees.

Employees may recognize their expertise and knowledge in an area within an organization by clearly understanding the procedures one employs at work (Amabile, 1988; Sawyer, 1992). This enhances understanding, and in turn, allows employees to further obtain related, right knowledge and information to perform the job. Likewise, it also aids in the identification of successfully areas that might need further improvement in performance. This helps direct the attention of the employees and help to acquire valuable knowledge and abilities to change their behavior and help them fit into their jobs.

\subsection{Relationship between Employee Creativity and Performance}

Creativity refers to the generation of the original idea which is about the novel, unanticipated and valuable thoughts (Amabile, 1983; Oldham \& Cummings, 1996; Shalley \& Zhou, 2008). Baldwin (2008) defines performance as undertaking 
actions efficiently and effectively for the achievement of agreed job objectives. It is evident that creativity is considered as an important competency for both organizations and employees (Gino \& Ariely, 2011; West, 2002); as it effectively facilitates problem solving by employees (Mumford \& Gustafson, 1998) and allows flexibility on the job (Flach, 1990). Furthermore, creativity enables employees to accept and exploit new opportunities within their workspace (Runco, 2004). Hence, creativity is needed to maintain the competitiveness and survival of organizations to meet customers' demands (Oldham \& Cummings, 1996; West, 2002).

Shalley, Zhou \& Oldham (2004) contended that the application of fresh or useful ideas can help improve the work of employees for better organizational performance. Meaning when employees become creative in an organization, it makes the organization have an edge over its competitors and may in turn increases the financial performance of the organization (Deshpandé et al., 1993). Apart from the increasingly key role of creativity in improving performance on the job, employees may also need to create an enabling and supportive culture that encourages worker creativity as it has also been recognized as a key enabler of firm innovation (Dul \& Ceylan, 2014; Miron-Spektor \& Beenen, 2015).

Also, the exhibition of creative behaviors by employees helps in the generation of competitive advantages and better returns for the organization (Woodman, Sawyer \& Griffin, 1993). Various researchers have argued that competitive advantage leads to revenue growth (Barney, 1986; Porter, 1985). Findings from Von Nordenflycht (2007), provides empirical support for the effect creativity has on revenue growth rates. Besides, Geroski (2000) proposed that there is an increase in profit when organizations encourage creative behaviors in their employees. Thus, there appears to be in the literature, a semblance of a positive relationship between employee creativity and performance. However, what is lacking is empirical evidence that supports such a relationship.

\section{Theoretical Background}

When employees are taken care by their organizations, according to the social exchange theory, there is an exchange relationship which promises to improve the performance of the organizational (Cropanzano \& Mitchell, 2005). When employees receive socio-emotional and economic resources of the organization, there is the feeling employees will pay back to the organization. For instance, employees dedicate their emotional and physical, cognitive resources when they are given training that fit their jobs; an, this helps improve their performance on the job (Karatepe, 2012).

Campbell et al., (1993) argued that the theory of performance concerns what needs to be done by a person to effectively undertake the job assigned by an organization. Based on this theory, procedures and skills knowledge, motivation and declarative knowledge are the factors that influence employee creativity and job performance. Campbell et al., (1993) further contended that knowledge about facts, self-knowledge, goals and principles which signifies an understanding of a specified task is regarded as declarative knowledge. They also said psychomotor abilities, cognitive abilities, self-management abilities, physical abilities, and interpersonal abilities are considered as practical knowledge and ability. When these three are combined, it leads to employee motivations (Campbell et al., 1993). Therefore, the three are closely linked to the competency of employees. It is therefore believed that when there is competent, it leads to the possession of the knowledge about requirements of core tasks and the necessary capabilities that reflect the abilities, attributes and the intention of an employee's creativity (Boyatzis, 1982).

The congruence theory of job design according to Barrett's (1978), expresses the importance of job fit between individual preferences and the job requirements or the knowledge skills and ability. Both components are widely believed to be essential to the satisfactory identification of an individual's creativity and retention level. When there is congruence existing between the employee and their job, it leads to positive creativity and motivational outcomes (Barrett, 1978; Edwards, 1991). Hence, the theory of performance, Social Exchange theory and the theory of Congruence are the theories underpinning this paper.

\section{Research Methodology}

In view of the aim and objectives of the study (examining the influence of job training-fit on employee creativity and performance) and other previous statements, the researcher opted for a qualitative research paradigm to help understand in-depth phenomena for a certain group, taking into consideration all relevant factors (Saunders, Lewis \& Thornhill, 2012). The research method was qualitative because it was exploratory in that the researcher was interested in the meaning gained from the observations and words; it involved fieldwork (Saunders et al., 2012). The researcher was the primary instrument for data collection and analysis. Case study was the design chosen for this research and a single entity or phenomenon was explored, bounded by time and activity (Creswell, 1994). Also, detailed information was collected using a variety of data collection procedures. These gave a comprehensive perspective, producing qualitative data, although some quantitative data were collected.

The study population was selected from core police officers (commanding officers of the various training schools, training instructors, some recruits in training and some security officers) from various departments within the Ghana Police Service.

The sample was randomly selected. The sampling was purposive to have heterogeneous representation. A homogenous sample was used to select Police Officers from various departments in order to concentrate on issues related to the influence of job training-fit on employee creativity and performance. The Police Officers were chosen on the basis of relevance to the topic of this study. A total of 6 commanding officers and 4 police recruits from the six police training schools and 5 police officers from different police departments were prior to the study contacted by phone. A number of them were difficult to contact. However, 2 commanding officers, 4 police recruits and 5 police officers were willing to take part in the research. 
Unstructured interviews were conducted as a data-gathering method. The researcher used this method due to the schedules of the respondents and the confidential nature of the Ghana Police Service, which makes the respondents reluctant to provide sensitive and confidential information. This method therefore provided the researcher the opportunity to receive immediate feedback and personally assured the respondents the information provided was strictly for research purpose. Information was recorded on tape, and in some cases I took notes during the sessions. Four sessions per participant were conducted over a period of 1 to 2 weeks. Interviews lasted between 15 and 25 minutes. The first two sessions were basically used to extract information from the participants. The third session came as a follow-up meeting aimed at clarifying all the unclear aspects and issues raised during the first two sessions so as to create a concrete understanding of the situation. During the third-round meetings in order to enhance validity, I offered parts from transcripts, together with field-notes, which contained a summarization and interpretation of the material during the unstructured interviews, to the interviewees to ensure accuracy and to facilitate further comments which I might have missed. Getting both the researcher and interviewees to collaborate on the writing up of interviews is a good way to enhance validity since it allows a more objective assessment (Humphrey \& Lee, 2004). The fourth session was mainly about validating the information with respondents and obtaining their views about the data that was gathered.

A set of interview questions was developed to probe the interviewee about his/ her role in the Ghana Police Service, how " is training fit understood, the institution's training, orientation, training infrastructure, and how the right people are selected for the security job. Questions that addressed internal efficiency, recruitment, training syllabus, review of training syllabus and performance were also included. In the study, each interview began with a preamble setting the parameters of the interview (length and audio taping), assuring confidentiality and the possibility of withdrawing from the study at any stage (Yin, 2002). The participants were assured that there were no right or wrong answers, rather their ideas, views and experiences were the important contributions to the study and also, they had the right to respond to any question (Copper \& Schindler, 2008). Consent was taken by the author prior to commencement of the interviews and all participants approached consented to the study except for two, due to unavailability of time (Saunders et al., 2012). All the interviews were conducted by the author in English, which was the mother tongue for most of the participants. Sociodemographic information, including contact information, educational level, place of work and demographic information, was obtained from all the participants before starting the interview. The recorded interviews were transcribed fully and verbatim, noting long pauses and non-verbal communications when thought to be important.

The researcher having worked as a police officer with the Ghana Police Service for close to 13 years, had relationships of varying degrees with some of the participants. This kind of relationship must have affected the amount of spontaneity in the interviews both positively and negatively. Nevertheless, the researcher started the interview by explaining to the participants that they were free to say what they thought and felt without trying to correct them. The researcher believed that being a retired police officer would have a positive effect on the interviews and would help him understand the meaning and aid interpretation of the participants' views. On the other hand, being a retired police officer could have reduced the researcher's ability to clearly recognize certain themes because he regarded them as normal.

The analysis was initiated based on the interview guide. The original themes derived from the Interview guide was assigned to sentences and paragraphs of data and inferential codes of data were put together. The coding moved from the descriptive to the more interpretative and a set of emergent themes were developed. The transcripts were read several times. Interesting and recurring ideas in addition to striking words and sentences were marked.

The original themes derived from the interview guide were assigned to sentences and paragraphs of the data. These were used as general themes while the recurring new ideas from units of data were put together. The end product of this process was that the original main themes were listed. The computer package NVivo was used to aid in the analysis.

\section{Results}

The qualitative methodology used in this study to report findings was done in a narrative form to facilitate the understanding of the meaning given by the participants to the topic. Analysis of the interview transcripts revealed three main themes related to the topic of study. 1. Perceived Advantages of job training-fit in the Ghana Police Service, 2. Conducting training needs assessment and 3 . Reviewing of the training syllabus.

\subsection{Demographics}

The demographic data from the participants showed that $55 \%$ were males $(n=6)$ and $45 \%$ were females $(n=5)$. $27 \%$ of participants were between the ages of $20-30(n=3), 55 \%$ of participants were between the ages of $30-40(n=6)$ and $18 \%$ of participants were 40 years and above $(\mathrm{n}=2)$. All participants in the sample had some level of education. $55 \%$ of participants were SHS holders $(n=6), 36 \%$ of participants were university graduate $(n=4)$ and $9 \%$ of participants were JHS holders $(n=1) .55 \%(n=6)$ of the participants, workers have worked in the police service for between 11 to15 years. $27 \%$ $(n=3)$ have been working for between 6 to 10 years and $18 \%(n=2)$ have been working for between 1 to 5 years.

(See Table 1). 


\begin{tabular}{|c|c|c|}
\hline Characteristic & N=11 & Percentage \\
\hline Gender & & \\
\hline Male & 6 & 55 \\
Female & 5 & 45 \\
\hline Age (years) & & \\
\hline $20-30$ & 3 & 27 \\
$31-40$ & 6 & 55 \\
Above 40 & 2 & 18 \\
\hline Education & & \\
\hline JHS & 1 & 9 \\
SHS & 6 & 55 \\
Graduate & 4 & 36 \\
\hline Work experience & & \\
(years) & & \\
\hline $1-5$ & 2 & 18 \\
6-10 & 3 & 27 \\
11-15 & 6 & 55 \\
\hline
\end{tabular}

Table 1: Demographic Data of the Sample

- Theme 1: Perceived Advantages of Job Training-Fit in the Ghana Police Service. All participants agreed that training an important strategy that help improves the attitudes and behavior of personnel in the Ghana Police Service. Performance was mentioned as an outcome of training. As an outcome, participants talked about the fact that through training, the personnel of the service who entered the police service with diverse educational backgrounds and personality orientations are able to understand the requirements of the service. Participants stressed that this helps personnel to easily accomplish their duties.

"When training is organized with the needs of personnel in mind, it's enhancing the knowledge, skills and abilities of the personnel involved. To me training is very good as it helps in developing personnel." participant 7 explained.

Other advantages of training, mentioned by the participants who were regarded as helpful Included a positive upsurge in the knowledge, skills and attitude of employees, which are necessary for both their current and future jobs. Participants declared that training helps them accept and learn new things which they never thought of before joining the Ghana Police Service. Other participants also stated that training enables the police service to recognize the expertise and knowledge of personnel in areas they are strong and can perform in. This will help in the placement of personnel at the right place after the training.

"To me training is very good, as a recruit and yet to pass out, I knew nothing about policing, but with 5 months of training, it has helped me to understand the operations of the police service and what is expected of me when I pass out from the training school." Participant 5 explained.

Some participants think that the bureaucratic nature of the Ghana Police service does not allow the outcomes of training to positively be felt. They contend that even though the training be organized by the service might be somewhat positive to personnel, the outcome of such training course in most cases are not accepted personnel who are senior to those officers who attended the training. Thus, the participants say in most cases make they realize that there do not benefit from the training they attend since they cannot implement the outcomes.

"Why can I attend a training course and spend time to learn new things that can help the development of the Ghana Police Service, yet after the training I cannot implement the outcome. For me, I do not think training in the Ghana Police Service is seen an important thing. Some of my colleagues have left the police service to other organizations after the service trained them." participant 5 explained

Creativity was also mentioned by the commanding officer of the national police training school asone of the outcomes of training. According to her, training equip personnel with the ability to apply fresh or useful idea to help them deal with problems and challenges that they might come across in line with the performance of their duties.

"As the commanding officer of this school, the innovativeness of all police personnel is achievable Through training. The level and nature of crime in this technological environment need creative personnel to deal with the same. As the head of the national police training, I have superintended number of training activities which have help improved the creativity levels of personnel." Participant 1 explained

Commitment to the police service was also mentioned as an advantage of training. Some

participants linked training to personnel commitment. They believed that when personnel are given training, they become happy with the performance of their duties and feel they owe the service. They said they feel the service has invested in their personal development and as such they need to stay and give back to the service.

"Sometimes I feel that the Ghana Police Service has done a lot for me as an instructor. I have been taken to a lot of training courses both internal and external. I have learnt a lot and I think I need to inculcate shame to the recruits and personnel who might be brought here. I have enough experience. I also help the service to achieve its objectives." participant 3.

All participants talked about issues related to the influence of job training-fit on performance in 
relation the Ghana Police Service. They spoke about the influence of job training-fit, reasons why training must fit job done by personnel. Commanding officers and training instructors talked about their roles in the organization of training and how job training-fit can influence the performance of the Ghana police service.

Participants mentioned several Influence of job training-fit on performance. For example, when job training-fit is extremely perceived it can influence the fulfillment of personnel need. They said this will help to increase the performance levels of personnel and also improves the capabilities of the personnel and brings optimistic change in the Ghana Police Service. In addition, they said that when training is specific, personnel better understand their job roles and responsibilities which translate into a bigger impact on performance of the Ghana Police Service. Another influence given is that when training is well planned and undertaken based on the demands of personnel it's led to positive influence on organizational performance

"It is possible if I have a training fit the job I do, it will help me to better understand the job I am Doing more... this will improve my performance and an individual. In that case lead to an improvement of the overall performance of the Ghana Police Service." participant 10.

- Theme 2: Conducting training needs assessment. Majority of the participants agreed to the fact that they do not think that the Ghana Police Service do conduct a training needs assessment before conducting or organizing training. They said the majority of the training that is conducted in the Ghana Police Service are done without meeting the specific training needs of personnel. The training instructors from the various polices training schools clearly indicated that at no point in time have they been involved in any form of training needs assessment before any training is organized as the following statements illustrate: "I think it's does not happen... because people at the top do not care about the needs of we those at the down-I have been working in this training school for the past 7 years and I am yet to be contacted for something like that." (Participant 1). "It would have been a good thing... however the police administration those not see the input of we the junior ranks as being important in the development of any training course. Even when we make recommendation or input to training issues they are ignored." (Participant 8)

Other participants stressed how uncomfortable they felt with most of the training course theyhave attended: "the training course I attended was bad because... I never felt I got what I wanted. Nobody asked me what my training needs were. After the training too, no feedback was asked. I think training in the Ghana Police Service is not necessarily" (participant 8); "I'm not surprised at all; the police service only organizes training just to create the impression to the public that they are training its personnel- however the things that need to be done to make the training a success and have targeted impact on the performance on the personnel are not done" (participant 8).

One participant responded enthusiastically, "Wow, training in the police service? And you think the police administration will find for me what my training needs are? That's funny, my brother they don't care ooo, Hmmm, I am yet to see that" (participant 11).

Most of the participants agreed to the fact that it was the duty of the Ghana police service to conduct training needs analysis in order to find out about the training needs of personnel before designing training programs for personnel of the service. Thus, the participants say will ensure that their training needs are met to help them perform their duties.

"I think it is the duty of the police administration, especially the training school and all other bodies that organize training for police personnel to identify the training needs of personnel. I even think that this should be done in line with changing crime environment and the abilities and capabilities of the personnel." (Participant 2).

- Theme 3: Reviewing of the training syllabus. All the Participants agreed that the training syllabus being used by the Ghana Police Service especially the one being used in the various police training schools is out of date. The commanding officers agreed that if the Ghana Police Service wants to become a democratic institution to meet international standard, then there is the need for the police administration to take a look at how best the current syllabus used at the various training school can reviewed as the following statements illustrate:

"...For example, I have been at the national police training school for more than 10 years as a classroom instructor. I have been teaching the same subject since I started teaching. No efforts have been made by the police administration to take a look at the syllabus being used. Policing now is totally different from policing 10 years ago. The level and types of crime have changed and it is only proper for the Ghana Police Service to change the content of their training to match same." participant 10.

Most participants agreed that if police officers are still behaving the way they are behaving, that is engaging themselves in criminal acts, police officers' involvement in crime, the widespread misuse of human rights, and governmental disturbance in its management, gives a clear indication that there is a problem with our training.

"We can do a lot, as an officer commanding, I think it is high time we try to look at some of the course we teach our recruits in training. I think some of the courses are irrelevant to modern policing. The police administration must do an assessment of our existing syllabus and review same. "Participant 7.

\section{Discussion}

In terms of the emergent themes, training was presented as a major emerging theme in this study. All participants stressed that training was an essential and effective strategy that help to increase the performance levels of personnel and also improves the skills and capability of the personnel and brings optimistic change in the police service, thus supporting findings of previous literature (Sultana, et al., 2012). In addition to this, participants added that training in the Ghana Police Service has a lot of advantages. Some participants mentioned the fact that, through training, the personnel of the service who entered the police service with diverse educational backgrounds and personality orientations are able to understand the requirements of the service (Hastie and Dawes, 2001). Participants repeatedly personnel, creativity as 
being the other advantages that training bring to the Ghana Police Service. The participants talked about the fact that training equip personnel with the ability to apply fresh or useful idea to help them deal with problems and challenges that they might come across in line with the performance of their duties. Thus, the participants say may help personnel to recognize their expertise and knowledge in areas they can fit within the police service by clearly understanding the procedures and obtain related, right knowledge and information one needs to employ in the performance of his/ her duties (Amabile, 1988; Sawyer, 1992).

This notwithstanding, Other participants stressed how uncomfortable they felt with most of the training course they have attended and even stated that they have been cases where some police officers who have trained have left the service to join other organizations thus supporting findings of previous literature (Glance, et al., 1997) that states that organizations often prefer to steal newly trained employees because of an upsurge in skills, knowledge and capabilities couple with their high-level performance. This they said can lead to organizations losing the entire investment made to employee train.

In the case of theme 2 , which looked at conducting training needs assessment, it is clear from the majority that the Ghana Police Service does not conduct a training needs assessment before conducting or organizing training. They believed because this, the training conducted does not meet the specific training needs of personnel. If it's obvious from the existing literature that when training is well planned and undertaken based on the demands of personnel by enhancing their knowledge, skills and abilities to perform effectively on their current job which significantly leads to positive effect on organizational performance (Cosh, et al., 2003). There is clear indication from the responds from the participants that training programs organized in the Ghana Police Service does not in any way fit the jobs of personnel. This might be the cause of the problems being faced by the police (CHRI, 2007). It is evident that even though training programs are organized, it lacks the positivity that will cause the upsurge in the knowledge, skills and attitude of personnel which are necessary for the performance of their duties. The responds also indicate clearly that there is the non-existence of congruence between the type of training (fit) and the duties performed by personnel. Barrett and O'Connell (1998) contended that that when training is specific, employees better understand their job roles and responsibilities which translate into a bigger impact on wages and productivity because it helps employees to feel more adjusted with their job allowing for more innovativeness on the job (Mason, Ark \& Wagner, 1996).

Theme 3 looked at reviewing of the training syllabus. All the Participants agreed that the training syllabus being used by the Ghana Police Service especially the one being used in the various police training schools were out of date. Organizations are more likely to achieve this synergy when they review their recruitment and selection processes, design an appropriate training system. Most participants agreed that if police officers are still behaving the way they are behaving, that is engaging themselves in criminal acts, police officers' involvement in crime, the widespread misuse of human rights, and governmental disturbance in its management, gives a clear indication that there is a problem with our training and as such the police administration should take a second look at its training syllabus.

Further, the data presented here, it is clear that when employees are taken care by their organizations, and there is an exchange relationship which promises to improve the performance of the organizational (Cropanzano \& Mitchell, 2005). When the right training is provided for employees, it increases competency of employees (Campbell et al., 1993). This leads to the possession of the knowledge about requirements of core tasks and the necessary capabilities that reflect the abilities, attributes and the intention of an employee's creativity (Boyatzis, 1982). Also, when there is congruence existing between the employee and their job, it leads to positive creativity and motivational outcomes (Barrett, 1978; Edwards, 1991). The findings of this study are therefore consistent with the theory of performance, Social Exchange theory and the theory of Congruence which are theories underpinning this paper.

\section{Limitation}

These findings should be viewed in light of several study limitations. Although the sample size was small, that was not considered a limitation as data saturation was reached for all themes. Even though the majority of the study participants were police officers working in the training schools for more years ( 3 to 6 years), few had less working experience. Those who design, formulate and implement policies in the training schools are the commanding officer; however out of the 6 commanding officers who had the six police training schools, only 2 participated in the study. The rest was not represented among the participants, and their perspectives were not reflected in the data and the findings of this study.

Also, fewer than $50 \%$ of the participants apart from the commanding officers were from the police training schools, compared to $70 \%$ in the larger police population. As such, the voices of the majority of the other police personnel would not have been heard, making it difficult to generalize the findings of this study. Because of the exploratory nature of this study, the researcher, highly recommends further research in different training settings. Any follow-up research should address several issues to overcome the limitations of this study. The suggestions for future research papers would be to try to conduct a quantitative study from a larger study population to generalize the findings.

\section{Implications of the Study}

The relevance of this study resides in the fact that police personnel were given the opportunity to express their views and what they perceive as the influence of job training-fit on their creativity and performance. Although these results cannot be generalized due to the qualitative nature of the study and the number of personnel who participated, the study came out with some interesting findings. The results suggest that when training is well planned and undertaken based on the demands of personnel by enhancing their knowledge, skills and abilities to perform effectively on their current job which significantly leads to positive effect on organizational performance (Cosh, et al., 2003). Therefore, to 
assure transfer of training, the police administration should provide the necessary time, money, equipment, facilities, and opportunities for the training, and take deliberate steps to ensure that the employees concerned believe the resources provided are enough, or at least adequate, for the particular purpose. The results also indicate that employees will respond better to training if they feel there is "something in it" for them. The police administration must provide intrinsic and extrinsic training incentives (e.g., money, positive feedback). The findings suggest that for training to be effective, it must fill a definite need that is recognized by the trainees themselves. The police administration should clearly state to their trainees how training could actually help them perform their jobs better. Barrett and O'Connell (1998) contended that that when training is specific, employees better understand their job roles and responsibilities which translate into a bigger impact on wages and productivity because it helps employees to feel more adjusted with their job allowing for more innovativeness on the job (Mason, Ark \& Wagner, 1996)

\section{Conclusion}

Training in the Ghana Police Service holds great promise for reaching an acceptable level performance of the service by the citizenry. For training in the police service to be successfully implemented, concerns raised by participants will need to be addressed, including the review of syllabi, conducting training needs assessment to ensure that linkage between the training and the duties performed by police personnel. Collaborations among stakeholders and other professionals with specialized, well planned and systematic training will provide an innovative approach to addressing these issues. The findings of this study show clearly that specific training programs targeted at of personnel are what is needed, but not the general form of training which in turn does not meet the needs of personnel. Also, if the police administration indeed wants the service to become a world class police service capable of delivering high standard performance, then the is the need for the police administration to take a second look at their overall training regime to ensure it conform with international standard.

\section{References}

i. Abudu, A. M., Nuhu, Y., \& Nkuahet, J. K. (2013). Bridging the security gap in Ghana: the role of private security actors. Developing Country Studies, 3(10), 11-30.

ii. Acton, T., \& Golden, W. (2003). Training the knowledge worker: A descriptive study of training practices in Irish software companies. Journal of European Industrial Training, 27(2-4), 137-146.

iii. Amabile, T. M. (1983). The social psychology of creativity: A componential conceptualization. Journal of Personality and Social Psychology, 45: 357- 376.

iv. Amabile, T. M., \& Gryskiewicz, S., S. (1987). Creativity in the R\&D laboratory. Technical report number 30, Center for Creative Leadership, Greensboro, NC.

v. Amabile, T. M. (1990). Within you, without you: The social psychology of creativity, and beyond.

vi. Amabile, T. M. (1996). Creativity in context. Boulder, CO: Westview Press.

vii. Ameeq, A. U., \& Hanif, F. (2013). Impact of training on employee's development and performance in hotel industry of Lahore, Pakistan. Journal of business studies quarterly, 4(4), 68-82.

viii. Aris, N.M. (2007). SMEs: building blocks for economic growth. Journal of the Department of Statistics Malaysia, 1, 1-14

ix. Baldwin, K. (2008). Managing Employee Performance in Seven Steps. Baldwin Kieran.

x. Ban, C., \& Faerman, S.R. (1990). Issues in the evaluation of management training. Public Productivity \& Management Review, 13(3), 271-286.

xi. Bandura, A. (1986). Social foundations of thought and action: A social cognitive theory. Englewood Cliffs, NJ: Prentice- Hall, Inc.

xii. Barrett, A. and O'Connell, P.J. (1998), Does training generally work? The returns to in company training, Centre for Economic Policy Research Paper No. 1879, London.

xiii. Barron, F., \& Harrington, D. M. (1981). Creativity, intelligence, and personality. Annual review of psychology, 32(1), 439-476

xiv. Becker, G. S. (1993) Human capital: A theoretical and empirical analysis with special reference to education (3rd ed.). Chicago, IL: University of Chicago Press.

xv. Bennett, H., \& Durkin, M. (2000). The effects of organizational change on employee psychological attachment: An exploratory study. Journal of Managerial Psychology, 15(2), 126-147.

xvi. Bhat, Z., H. (2014). Job matching: the key to performance. International Journal of Research in Organizational Behaviour and Human Resource Management, 2(4), 257-269.

xvii. Bhat, Z.H. (2013). Impact of training on employee performance: A study of retail banking sector in India. Indian Journal of Applied Research, 3(6), 292-293.

xviii. Bolino, M. C., \& Grant, A. M. (2016). The bright side of being prosocial at work, and the dark side, too: A review and agenda for research on other-oriented motives, behavior, and impact in organizations. The Academy of Management Annals (in press)

xix. Brett, J. F., \& VandeWalle, D. (1999). Goal orientation and specific goal content as predictors of performance outcomes in a training program. Journal of Applied Psychology, 84: 863- 873.

xx. Brown, S.P. (1996). A meta-analysis and review of organizational research on job involvement. Psychological Bulletin, 120(2), 235-255.

xxi. Cable, D.M., \& Edwards, J.R. (2004). Complementary and supplementary fit: a theoretical and empirical integration. Journal of Applied Psychology, 89 (5), 822-834 
xxii. Cable, D.M., \& De Rue, D.S. (2002). The convergent and discriminant validity of subjective fit perceptions. Journal of Applied Psychology, 87(5), 885-893

xxiii. Chen, G.\& Klimoski, R. J. (2007). Training and development of human resources at work: Is the state of our science strong?', Human Resource Management Review, 17, 180-90.

xxiv. Chenhall, R., H. (2005) Integrative strategic performance measurement systems, strategic alignment of manufacturing, learning and strategic outcomes: an exploratory study. Account. Organ. Soc., 30, 395-422.

xxv. Cooper, D., Schindler, P. (2008). Business research methods (10th ed.). New York, McGraw-Hill/ Irwin.

xxvi. Cosh, A., Hughes, A., Bullock, A. and Potton, M. (2003), The relationship between training and business performance, DfEE Research Report No. 245, London.

xxvii. Creswell, J. (1994). Research design: Qualitative and quantitative approaches. Thousand Oaks, CA: Sage.

xxviii. Delbridge, R. and T. Keenoy (2010) 'Beyond managerialism?', The International Journal

xxix. Deshpandé, R., J. Farley, and F. Webster, Jr. (1993). "Corporate Culture, Customer Orientation, and Innovativeness" Journal of Marketing

xxx. 57(1): 23-27.

xxxi. Diamantidis, A.D., \& Chatzoglou, P.D. (2012). Evaluation of formal training programs in Greek organisations. European Journal of Training and Development, 36(9), 888-910

xxxii. Dul, J., \& Ceylan, C. (2014). The Impact of a Creativity-supporting Work Environment on a Firm's Product Innovation Performance. Journal of Product Innovation Management, 31(6), 1254-1267.

xxxiii. Dweck, C. S., \& Leggett, E. L. (1988). A social-cognitive approach to motivation and personality. Psychological Review, 95: $256-273$.

xxxiv. Eisenhardt, K.M., (1989). Building theories from case study research. Academy Management Review., 14(4), 532550

xxxv. Erdogan, B., \& Bauer, T.N. (2005). Enhancing career benefits of employee proactive personality: The role of fit with jobs and organizations. Personnel Psychology, 58(4), 859-891.

xxxvi. Flach, F. (1990). Disorders of the pathways involved in the creative process. Creativity Research Journal, 3, 158165

xxxvii. Gagné, M. and Deci, E. L. (2005), 'Self-determination theory and work motivation', Journal of Organizational Behavior, 26, 331-62.

xxxviii. Gardner, W. L., Avolio, B. J., Luthans, F., May, D. R., \& Walumbwa, F. O. (2005). “Can you see the real me?” A selfbased model of authentic leader and follower development. Leadership Quarterly, 16, 343-372.

xxxix. Geroski, P. (2000). "The Growth of Firms in Theory and in Practice." Chapter in Competence, Governance, and Entrepreneurship: Advances in Economic Strategy Research. Eds. N. Foss and V. Mahnke. New York, NY: Oxford Press, pp. 168

xl. Gino, F., \& Ariely, D. (2011). The dark side of creativity: Original thinkers can be more dishonest. Journal of Personality and Social Psychology, 102, 445-459

xli. Glance, N.S., Hogg, T., and Huberman, B.A. (1997) Training and turnover in the evolution of organizations. Organization Science. Vol. 8 no.1, pp. 84-96.

xlii. Gong, Y., \& Fan, J. 2006. Longitudinal examination of the role of goal orientation in cross-cultural adjustment. Journal of Applied Psychology, 91: 176 -184.

xliii. Grant, A. M., \& Berg, J. M. (2011). Prosocial motivation at work: When, why, and how making a difference makes a difference. In K. Cameron \& G. Spreitzer (Eds.), Handbook of positive organizational scholarship Oxford, UK: Oxford University Press

xliv. Guest, D.E. (1997). Human resource management and performance: A review and research. The International Journal of Human Resource Management, 8(3), 263-276

xlv. Hackman, J. R. and Oldham, G. R. (1976), 'Motivation through the design of work: test of a theory', Organizational Behavior and Human Performance, 16, 250-79.

xlvi. Hastie, R. and Dawes, R.J. (2001) Rational Choice in an Uncertain World: The psychology of judgement and decision making. Sage, Thousand Oaks, CA, US. Hogarth, R.M. (2001) Educating Intuition. University of Chicago Press, Chicago.

xlvii. Hayes, J. R. (1989). Cognitive processes in creativity. In J. A. Glover, R. R. Ronning, \& C. R. Reynolds (Eds.), Handbook of creativity: 135-145. New York: Plenum

xlviii. Herselman, S. (2001). Performance Motivation Among Employees of a Wholesale Company, Journal of Ethonology, 24(1), 1-10.

xlix. Hult, G., T., M., Ketchen, D., J. \& Nichols, E., L., J. (2003). Organizational learning as a strategic resource in supply management. Journal of Operation Management, 21, 541-556.

1. Humphrey, C. and Lee, B. (2004), The Real-Life Guide to Accounting Research, Elseiver, Oxford.

li. Kalliath, T.J., Bluedorn, A.C., \& Strube, MJ. (1999). A test of value congruence effects. Journal of Organizational Behavior, 20(7), 1175-1198.

lii. Kanungo, R.N. (1979). The concepts of alienation and involvement revisited. Psychological Bulletin, 86(1), 119139.

liii. Karia, N., \& Ahmad, Z.A. (2000). Quality practices that pay: Empowerment and team work. Malaysian Management Review, 35(2), 66-76. 
liv. Kozlowski, S., W., J, Gully, S., M, Brown, K., G, Salas, E., Smith E., M, Nason E., R. (2001). Effects of training goals and goal orientation traits on multidimensional training outcomes and performance adaptability. Organ. Behav. Hum. Decis. Process. 85:1-31

lv. Kraiger, K. \& Ford, J. K. (2007). The Expanding Role of Workplace Training: Themes and Trends Influencing Training Research and Practice', in L. L. Koppes (ed.), Historical Perspectives in Industrial and Organizational Psychology (Mahwah, NJ: Lawrence Erlbaum Associates), pp. 281-309.

lvi. Kreitner, R \& Kinicki, A. (2004). Organisational Behavior. New York: McGraw-HilI.

lvii. Kristof-Brown, A. (2000) Perceived applicant fit: Distinguishing between recruiters' perceptions of person-job and person- organization fit. Personnel Psychology, 53, 643-671.

lviii. Lewis, M., W. (1998). Iterative triangulation: a theory development process using existing case studies. Journal of Operation Management, 16, 455-469.

lix. Li, Y., \& Bai, X. (2015). Creating for others: An experimental study of the effects of intrinsic motivation and prosocial motivation on creativity. Advances in Psychological Science, 23, 175-181

lx. Lowry, D. S., Simon, A., \& Kimberley, N. (2002). Toward improved employment relations practices of casual employees in the New South Wales registered club's industry. Human Resource Development Quarterly, 13(1), 53-69.

lxi. Mason, G., van Ark, B. and Wagner, K. (1996), Workforce Skills, Product Quality and Economic Performance, Acquiring Skills: Market Failures, their Symptoms and Policy Responses, Cambridge University Press, Cambridge.

lxii. Meredith, J. (1998). Building operations management theory through case and field research. Journal of Operation Management, 16, 441-454.

lxiii. Miron-Spektor, E., \& Beenen, G. (2015). Motivating creativity: The effects of sequential and simultaneous learning and performance achievement goals on product novelty and usefulness. Organizational Behavior and Human Decision Processes, 127, 53-65.

lxiv. Mowday, R.T., Porter, L.W., \& Steers, R.M. (1982). Organizational linkages: The psychology of commitment, absenteeism, and turnover. New York, NY: Academic Press.

lxv. Mullins, J., L. (2007) Management and Organisatioal Behaviour ( $7^{\text {th }}$ edn).

lxvi. Mumford, M. D., \& Gustafson, S. B. (1988). Creativity syndrome: Integration, application, and innovation. Psychological Bulletin, 103, 27-43

lxvii. Nawaz, M. S., Hassan, M., Hassan, S., Shaukat, S., \& Ullah, A. (2014). Impact of Employee Training and Empowerment on Employee Creativity through Employee Engagement: Empirical Evidence from the Manufacturing Sector of Pakistan. World Applied Sciences Journal, 32(5), 921-929

lxviii. Oldham, G.R. \& Cummings, A. (1996). "Employee creativity: personal and contextual factors at work", Academy of Management Journal, 39(3):607-34

lxix. Obisi, C. (2011). Employee training and development in Nigerian organizations: Some observations and Agenda for research. Australian Journal of Business and Management Research, 1(9), 82.

lxx. Podsakoff, P.M. \& MacKenzie, S.B. (1997). Impact of organizational citizenship behavior on organizational performance: A review and suggestions for future research. Human Performance, 10(2), 133-151.

lxxi. Porter, M.E. (1985), Competitive Advantage: Creating and Sustaining Superior Performance, Free Press, London

lxxii. Resick, C.J., Baltes, B.B., \& Shantz, C. (2007). Person-organization fit and work-related attitudes and decisions: Examining interactive effects with job fit and conscientiousness. Journal of Applied Psychology, 92(5), 1446-1455.

lxxiii. Roca, J. C. \& Gagné, M. (2008), 'Understanding e-learning continuance intention in the workplace: a selfdetermination theory perspective', Computers in Human Behavior, 24, 4, 1585-604.

lxxiv. Rowden, R.W. (2002). The relationship between workplace learning and job satisfaction in U.S. small to midsize businesses. Human Resource Development Quarterly, 13, 407-425.

lxxv. Runco, M. A. (2004). Creativity. Annual Review of Psychology, 55, 657-687.

lxxvi. Sahinidis, A.G., \& Bouris, J. (2008). Employee perceived training effectiveness relationship to employee attitudes. Journal of European Industrial Training, 32(1), 63-76.

lxxvii. Saunders, M., Lewis, P. and Thornhill, A. (2012) Research Methods for Business Students (6th ed.), Pearson Education Limited: Essex, England

lxxviii. Saks, A. (2006). Antecedents and consequences of employee engagement. Journal of Managerial Psychology, 21(6), 600-619

lxxix. Saks, A.M., \& Ashforth, B.E. (2002). Is job search related to employment quality? It all depends on fit. Journal of Applied Psychology, 87 (2), 646-54

lxxx. Sawyer, J. E. (1992). Goal and process clarity: Specification of multiple constructs of role ambiguity and a structural equation model of their antecedents and consequences. Journal of Applied Psychology, 77, 130-142.

lxxxi. Schaufeli, W.B., \& Taris, T.W. (2014). A critical review of the job demands-resources model: Implications for improving work and health. In Georg F. Bauer (Ed.), Bridging occupational, organizational and public health (pp. 43-68). Dordrecht, Netherlands: Springer.

lxxxii. Schneider B. (2001). Fit about fit. Appl. Psychol., 50(1): 141-152.

lxxxiii. Schein, E.H. (2006). Organizational culture and leadership. San Francisco, CA: John Wiley and Sons.

lxxxiv. Shalley, C.E., Zhou, J. \& Oldham, G.R. (2004), "The effects of personal and contextual characteristics on creativity: where should we go from here?" Journal of Management, 30(6):933-58.

lxxxv. Shalley, C. E., \& Zhou, J. (2008). Organizational Creativity Research. In C. E. Shalley \& J. Zhou (Eds.), Handbook of Organizational creativity (pp. 3-23). New York: Taylor \& Francis Group, LLC. 
lxxxvi. Sultana, A., Irum, S., Ahmed, K., \& Mehmood, N. (2012). impact of training on employee performance a study of telecommunication sector in Pakistan. Interdisciplinary journal of contemporary research in business, 4(6), 646661.

lxxxvii. Swart, J., Mann, C., Brown, S., \& Price, A. (2005). Human resource development: Strategy and tactics. Oxford, UK: Elsevier Butterworth-Heinemann Publications.

lxxxviii. Tannenbaum, I.S., Mathieu, E.J., Sales, E., \& Cannon-Bowers, A.J. (1991). Meeting trainees' expectations: The influence of training fulfillment on the development of commitment, self-efficacy, and motivation. Journal of Applied Psychology, 76(6), 759-769.

lxxxix. Treven, S (2001). Human resource management in international organizations. Management, 6(1-2), 177-189.

xc. Turner M, Imbaruddin A \& Sutiyono W (2009) Human resource management: the forgotten dimension of decentralisation in Indonesia, Bulletin of Indonesian Economic Studies 45(2): 231-249

xci. VandeWalle, D., Brown, S. P., Cron, W. L., \& Slocum, J. W. (1999). The influence of goal orientation and selfregulation tactics on sales performance: A longitudinal field test. Journal of Applied Psychology, 84: 249 -259.

xcii. Vogel, R. M. \& Feldman, D. C. (2009). Integrating the levels of person-environment fit: the roles of vocational fit and group fit. Journal of Vocational Behavior, 75(1), 68-81.

xciii. Von Nordenflycht, A. (2007), "Is Public Ownership Bad for Professional Service Firms? Ad

xciv. Weisberg, R. W. (1999). "Creativity and knowledge: a challenge to theories," in Handbook of Creativity, ed R. J. Sternberg (Cambridge, UK: Cambridge University Press), 226-250.

xcv. West, M. (2002). Sparkling fountains or stagnant ponds: An integrative model of creativity and innovation. Journal of Applied Psychology, 51, 355-387

xcvi. Wood, G., \& Budhwar, P.S. (2016): "Brexit and Beyond: The BJM and Unforeseen Events." British Journal of Management, 27 (4), 680-681.

xcvii. Woodman, R., Sawyer.J, \& Griffin.R. (1993). "Toward a Theory of Organizational Creativity." Academy of Management Review 18: 293-321.

xcviii. Yevugah, D., \& Caesar, L. (2018). Examining the Effects of Job Training-Fit on Employee Creativity and Performance. The International Journal of Business \& Management, 6 (4), 15-22.

xcix. Yin, R., K. (1994) Case Study Research: Design and Method, 2nd edn. Sage Publications, London, UK.

c. Yin, R., K. (2002). Case Study Research: Design and Methods, Sage Publications: California.

ci. Zheng C, Hyland P \& Soosay C (2007) Training practices of multinational companies in Asia, Journal of European Industrial Training 31(6): 472-494 